\title{
Hook ingestion rates in loggerhead sea turtles Caretta caretta as a function of animal size, hook size, and bait
}

\author{
Lesley W. Stokes ${ }^{1, *}$, Dominy Hataway ${ }^{2}$, Sheryan P. Epperly ${ }^{1}$, Arvind K. Shah ${ }^{3}$, \\ Charles E. Bergmann ${ }^{2}$, John W. Watson ${ }^{4}$, Benjamin M. Higgins ${ }^{5}$
}

${ }^{1}$ National Marine Fisheries Service, Southeast Fisheries Science Center, 75 Virginia Beach Drive, Miami, Florida 33149, USA

${ }^{2}$ National Marine Fisheries Service, Southeast Fisheries Science Center, PO Drawer 1207, Pascagoula, Mississippi 39568, USA ${ }^{3}$ Merck Research Laboratories, PO Box 2000, RY34-A312, Rahway, New Jersey 07065, USA

${ }^{4}$ National Marine Fisheries Service, Southeast Fisheries Center, 5131 North Drive, Moss Point, Mississippi 39563, USA

${ }^{5}$ National Marine Fisheries Service, Southeast Fisheries Science Center, 4700 Ave U, Galveston, Texas 77551, USA

\begin{abstract}
Declines in sea turtle populations worldwide have been attributed in part to incidental capture in hook and line fisheries. Methods to reduce turtle bycatch and mortality must strike a balance between bycatch reduction and target species retention if they are to gain acceptance from fishers. To investigate potential bycatch reduction measures, we examined the effects of hook size, bait type, baiting technique, and animal size on the frequency of loggerhead sea turtles Caretta caretta ingesting a baited hook during controlled trials. Results indicated that as hook size increased, the likelihood for deep ingestion decreased. Smaller turtles were less likely to swallow larger hooks. Turtles were less likely to swallow hooks baited with sardines than with squid and single-baited rather than threaded baits. Results are likely due to differences in bait texture, hook shielding effects, and turtles' behavioral differences. We suggest that fishing with large hooks, using finfish instead of squid, and using single-baited instead of threaded baits might reduce deep ingestion rates of hooks by loggerheads as large as $65 \mathrm{~cm}$ in standard straight carapace length (notch to tip).
\end{abstract}

KEY WORDS: Loggerhead $\cdot$ Caretta caretta $\cdot$ Bycatch $\cdot$ Longline fishing $\cdot$ Sea turtle $\cdot$ Experimental

\section{INTRODUCTION}

Sea turtles are protected by the United States Endangered Species Act of 1973 and similar laws internationally, with 5 species listed as Endangered or Critically Endangered on the International Union for Conservation of Nature (IUCN) Red List (IUCN 2009). Declines in sea turtle populations worldwide have been attributed in part to their incidental capture in fisheries (Hillestad et al. 1995, Lutcavage et al. 1997, Wallace et al. 2010). For example, incidental capture in pelagic longline fishing gear targeting swordfish Xiphias gladius, tuna Thunnus spp., mahi-mahi Coryphaena hippurus, and various shark species has the potential to kill or seriously injure thousands of sea tur- tles every year (Camiñas 1997, Witzell 1999, Lewison et al. 2004). Solutions to reduce the frequency and severity of fishery interactions are imperative to protect these species and to promote recovery.

Measures to reduce sea turtle bycatch in hook and line fisheries include modifications of fishing gear and bait, soak time limitations, minimum gear depth requirements, and time-area closures (see Gilman et al. 2006 for a review). However, more research on bycatch mitigation is warranted (Hamann et al. 2010), and bycatch reduction methods must strike a balance between bycatch reduction and target species retention to gain widespread acceptance by fishers. Of the potential mitigation measures, we suggest that those that focus on hook and bait combinations may provide 
cost-effective, transferrable solutions for protecting both fishery and sea turtle interests in regions and fisheries where they are found to be effective.

Sea turtles generally interact with hook and line gear by becoming externally hooked and/or entangled (particularly leatherbacks Dermochelys coriacea) or by ingesting the hook and bait (particularly loggerheads Caretta caretta and other cheloniids; Watson et al. 2005). Turtles may be attracted to the bait, light sticks (Lohmann et al. 2006, Wang et al. 2007), or other components of fishing gear, such as floats or buoys (Watson et al. 2005). Turtles captured on shallow-set pelagic gear can generally reach the surface to breathe, resulting in a low initial mortality rate observed at gear retrieval (Aguilar et al. 1995, NMFS 2001, Camiñas 2004, Lewison \& Crowder 2007). Drowning can be a source of direct mortality (Work \& Balazs 2002), particularly when entanglement is a factor or when longlines are set deep (Jribi et al. 2008). Therefore, while the interactions are variable, hooking location and the amount of remaining gear may have serious implications for mortality after release (Ryder et al. 2006).

Concern over sea turtle mortality has led to previous closures of economically important fishing grounds, such as the US closure of the Northeast Distant (NED) area in the western North Atlantic (USDOC 2000a, 2001a,b) and the Hawaii-based pelagic longline swordfish fishery (USDOC 1999, 2000b). Such management closure actions are controversial and have clear economic and social consequences. They may also displace fishing effort, creating unintended impacts on other bycatch and target species or regions. Additionally, closure of fishing grounds in international waters to one fleet may not reduce total effort in the area, as other nations' fleets may move in to fish the available space. Ideally, mitigation measures to reduce sea turtle mortality in fisheries would avoid these unintended consequences, would be relatively inexpensive to implement, and would minimize any reduction in target species catch.

Several field studies have investigated mitigation measures such as hook type and size, bait type, and/or fishing depth (Boggs 2004, Bolten \& Bjorndal 2005, Watson et al. 2005, Hall 2006, 2008). Studies in the western North Atlantic Ocean investigated how various hook sizes and styles, sometimes in combination with squid or finfish bait treatments, would impact sea turtle bycatch and target catch (Bolten \& Bjorndal 2005, Watson et al. 2005). Large (18/0 hook size varies by manufacturer, see 'Materials and methods' for hook measurements in $\mathrm{mm}$ ) circle hooks baited with mackerel were highly effective in reducing loggerhead turtle interactions by as much as $90 \%$ compared to $9 / 0 \mathrm{~J}$ hooks $\left(25-30^{\circ}\right.$ offset) baited with Illex spp. squid (Watson et al. 2005), which was previously the industry standard in the US western Atlantic pelagic longline swordfish fishery. Rule modifications based upon these encouraging results were enacted in 2004, re-opening both the Hawaii-based shallow-set fishery and the NED fishery (USDOC 2004a,b). Furthermore, in the Atlantic, the US fishery was mandated to use 16/0 (non-offset, outside the NED statistical reporting area) or $18 / 0$ (maximum $10^{\circ}$ offset, within the NED) or larger circle hooks.

Additional research is needed to further reduce the impact of hook and line fishing on marine turtles, as methods may not be applicable to all fisheries, regions, species, and size classes (Read 2007), and the success of the regulations is yet to be verified through bycatch analysis. Bait type and baiting technique are potentially important features that might influence whether a hook is deeply ingested and whether serious injury occurs as a consequence. Previous laboratory trials demonstrated that as hook size increases, the percentage of turtles ingesting hooks decreases (NMFS unpubl. data). Our study further investigated how hook size, bait type, and baiting technique affect ingestion rates in 3 size classes of juvenile loggerheads.

We selected squid Illex illecebrosus for this study because it is an industry standard in the Atlantic and Gulf of Mexico pelagic longline fishery (Beerkircher et al. 2004). We chose sardines Sardinella aurita because they are the finfish most often used in the Gulf of Mexico pelagic longline fishery targeting tuna, and we considered that they would be representative of different finfish used in other regions or fisheries. A variety of finfish, primarily Atlantic mackerel Scomber scombrus and sometimes fish from the Clupeidae (sardine, herring, and shad) and Carangidae (jack and scad) families are used by the pelagic longline fishery (Beerkircher et al. 2004). Sardines were selected to maintain bait texture and preserve water quality under our test conditions, as well as to maintain consistent size availability within each lot.

We suspect that under normal fishing operations, those turtles that took a true circle hook partially or fully into their mouth, if hooked, would have been hooked somewhere in the mouth or the beak. Those that attempted to swallow would have a higher probability of being hooked in the esophagus; therefore, we chose to focus on the 'attempted to swallow' response category for this study to investigate methods to reduce deep ingestion rates.

The hypotheses tested were: (1) as turtle size increases, the turtle's frequency of swallowing a hook of a given size increases; (2) as hook size increases, the frequency of a turtle of a given size swallowing a hook decreases; (3) turtles are more likely to swallow squid than sardines because the latter can be torn off the 
hook more easily; (4) turtles are more likely to swallow hooks that are threaded than single-baited because the bait is less likely to strip away when threaded; and (5) changing baiting technique will lead to greater reductions in the frequency of deep ingestion rates with sardines than squid due to differences in bait texture.

We observed and videotaped turtle feeding behaviors. Our goal was to assess what hook and bait combinations have the greatest potential to reduce the severity of incidental sea turtle captures in pelagic longline gear.

\section{MATERIALS AND METHODS}

Experimental protocols. This research was conducted at the NMFS Galveston, Texas, USA, laboratory in April 2004, October 2004, and May 2005. Subjects were captive-reared loggerheads collected as hatchlings on Florida beaches in 2001; 60 turtles were reared on a diet of floating pellet food for the first $2 \mathrm{yr}$ and then on a fish diet (Higgins 2003), to a targeted mean size of $45 \mathrm{~cm}$ standard straight carapace length $\left(\mathrm{SCL}_{\mathrm{std}}\right)$, measured from the anterior point at midline of the nuchal scute to the posterior tip of the supracaudals (Bolten 1999) (mean $\pm \mathrm{SD}=45.3 \pm 1.37 \mathrm{~cm}, \mathrm{n}=60$, range 42.3 to $48.3 \mathrm{~cm}$ ). Thirty of the largest turtles were retained for subsequent trials when they reached $55 \mathrm{~cm} \mathrm{SCL}_{\text {std }}$ (mean $56.0 \pm 1.71 \mathrm{~cm}, \mathrm{n}=30$, range 53.3 to $59.8 \mathrm{~cm}$ ), and $65 \mathrm{~cm} \mathrm{SCL}_{\text {std }}$ (mean $63.9 \pm 2.10 \mathrm{~cm}, \mathrm{n}=$ 30 , range 60.9 to $69.9 \mathrm{~cm}$ ). The 3 size groups were then labeled as 45,55 , and $65 \mathrm{~cm}$ size classes. These mean sizes encompass published size ranges (46 to $64 \mathrm{~cm}$ curved carapace length, CCL) for pelagic stage loggerheads in the western North Atlantic (Bjorndal et al. 2000, Snover 2002) and loggerhead turtles observed captured in the US pelagic longline fishery in the Atlantic and Gulf of Mexico (mean SCL std: $_{\text {: }}$ $58.7 \pm 6.67 \mathrm{~cm}, \mathrm{n}=541$, range 32.4 to $77.9 \mathrm{~cm}$; NMFS unpubl. observer data). The hook sizes selected for the trials $\left(14 / 0,16 / 0,18 / 0\right.$, and 20/0 Mustad ${ }^{\circledR}$ 39960D circle hooks, modified; Fig. 1) represent the range of those potentially used by the fleet. During the experiments, the turtles were exposed to all of the hook sizes except that the 20/0 hooks were not used in the first set of trials because they were too large for the $45 \mathrm{~cm}$ turtles to ingest. In each treatment, $\sim 20$ turtles were systematically selected from the pool of available animals, starting in assigned positions within the raceways on a rotating basis so that animals were used at varying times throughout each day. All turtles were transported back to Florida waters at the completion of the study in accordance with permit conditions.

To prevent injury, the barb of each hook was removed, the end was ground smooth with a rotary tool, and heat shrink tubing was secured to the end of the hook. After the hook was baited, the free end of the heat shrink tubing was affixed to the shank of the hook using 2 cable ties, which were trimmed even with the hook. Hooks were affixed to a short $(\sim 2.0 \mathrm{~m})$ length of $400 \#$ test monofilament line using a single aluminum crimp. It is important to note that because of the modifications, these hooks can no longer be considered circle hooks. Hook width, but not hook style, was the relevant parameter tested in these trials.

In the first round of trials using the $45 \mathrm{~cm}$ size class of turtles, shrink wrap tubing color varied (white, blue, yellow, and black) at the beginning of the trial, but in subsequent trials we used only black shrink wrap. Subsequent analyses (videotapes and data) revealed no effect of shrink wrap color on feeding behavior.

Baits (whole short-finned squid Illex illecebrosus, whole Spanish sardines Sardinella aurita) were 'single-baited' or 'threaded' on the hooks. Single-baited squid was hooked once in the mantle at the midpoint between the fins; single-baited sardines were hooked through the eye. Threaded baits were hooked through the aforementioned locations, and then again distal to the initial point of entry at a distance determined by the hook width. Baits were weighed each day, and the average of 10 pieces was recorded to ensure size consistency throughout the trials.

The turtles were individually housed in rectangular fiberglass raceways subdivided into sections $\sim 1.8 \mathrm{~m}$

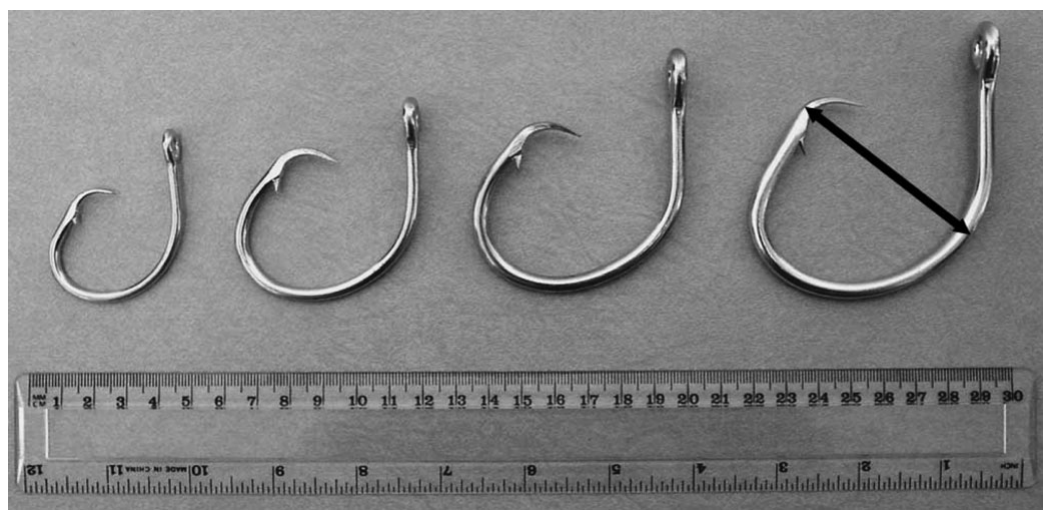

Fig. 1. Caretta caretta. Mustad ${ }^{\circledR}$ 39960D circle hooks (from left to right: 14/0, $35.7 \mathrm{~mm}$ minimum hook width; 16/0, $46.0 \mathrm{~mm}$; 18/0, $51.3 \mathrm{~mm}$; and 20/0, $62.1 \mathrm{~mm}$ ) before modification. The $20 / 0$ hook is marked with an arrow to indicate the minimum hook width, considered in this study the most relevant parameter in considering a turtle's physical potential to swallow the hook 
wide by $2 \mathrm{~m}$ long and $1 \mathrm{~m}$ deep. The turtles were not fed for $3 \mathrm{~d}$ prior to testing, and they were not fed except during the trials for the duration of each testing period. They were not moved from their holding tanks to conduct trials. Individual trials were selected randomly each morning, and each turtle participated in 2 trials $\mathrm{d}^{-1}$, once in the morning and once in the afternoon after at least a $4 \mathrm{~h}$ period of rest. Motivation to feed was uniformly high during the 2 trials, as none of the turtles were offered enough food to approach satiation.

During each feeding trial, a baited hook was suspended above the bottom of the tank. As soon as the turtle touched the bait, tension on the leader was released, allowing the turtle to feed (in some cases) off the bottom of the tank. The trial continued until the bait had been eaten or stripped from the hook. If the turtle showed no interest in the bait after $\sim 2 \mathrm{~min}$, the individual was excluded from that trial, and another turtle was used.

Each turtle's reaction to the baited hook was coded as 1 of 4 possible response categories: 'did not take hook into mouth' (DNT), when no part of hook entered the mouth; 'partially in mouth' (PIM), when part of hook was taken into the mouth; 'fully in mouth' (FIM), when the entire hook up to the eye was taken into the mouth; or 'attempt to swallow' (ATS), when the entire hook including the eye and the crimp entered the mouth. If a turtle attempted to swallow the bait, the baited hook was removed immediately to eliminate any risk of injury. Trials were videotaped underwater to record the behavioral details of the interaction and to confirm the response categories. After the trials, standard (straight carapace length standard and minimum, straight carapace width, head length and head width; Bolten 1999) and oral cavity measurements were taken for future comparisons quantifying relationships between turtle size, oral cavity volume, and hook ingestion potential.

Statistical methods. The data were first analyzed using 2 sets of logistic regression models (1 model using categorical variables and another using categorical and continuous variables) based upon binary (yes or no) responses for the ATS response category. Initially, all 2-factor interaction terms were included in the models, but were subsequently dropped because they were not significant. Thus, the final models only included main effect terms (turtle size class, hook size, bait type, and baiting technique). Because these 2 model types present useful results, one for direct comparisons between categories and the other for predicting odds across a range of measured parameters, we report the results from both model sets. The odds ratios and corresponding $95 \%$ confidence intervals were computed for these fitted models for comparing odds for each category between different size classes, hook sizes, bait types, and baiting techniques.

Finally, a multinomial logistic regression model was used to estimate the probability of a turtle's response in all 4 response categories (DNT, PIM, FIM, ATS) to further investigate the data. Although we chose to focus on the ATS response category for this study in order to explore methods with which to reduce deep ingestion rates, we considered it important to evaluate the results from each response category. Because the assumption of proportional odds by cumulative categories (in terms of severity) was not satisfied, a cumulative logit model was not explored further, and the multinomial logistic regression model was used.

Odds ratios: The 'odds ratio' is the ratio of odds of an event under one condition (e.g. a hook size or bait type or style) relative to the odds of the same event under a second condition (e.g. a different hook size or bait type or style). To calculate the odds ratio (e.g. comparing sardine versus squid bait), the odds of both events to be compared (e.g. the odds of a turtle attempting to swallow sardines and the odds of a turtle attempting to swallow squid) must be calculated first. The 'odds of an event' is the ratio of the probability of the event to the probability of the non-event, where the probability of the non-event is equal to 1 - probability of the event. For example, if the probability of ATS is 0.2 , then the odds for ATS are $(0.2 / 0.8)=1: 4$, meaning 1 ATS for every 4 non-ATS over multiple runs. Once the odds of an event for each condition have been computed, the odds ratio comparing 2 conditions can be constructed, as in the following example:

Odds ratio $\left(\right.$ Sar vs. Sq) $=\frac{\text { Probability of ATS } / \text { non-ATS event }(\mathrm{Sar})}{\text { Probability of ATS/non-ATS event }(\mathrm{Sq})}$ where Sar is sardine and Sq is squid. An odds ratio of 1 implies the events are equally likely to occur under both conditions.

Model with categorical variables: To investigate the effect of turtle size class $\left(45,55,65 \mathrm{~cm} \mathrm{SCL}_{\text {std }}\right)$, hook size $(14 / 0,16 / 0,18 / 0,20 / 0)$, bait type (sardine, squid), and baiting technique (single, threaded) on the response variable (ATS), a logistic regression model with these terms was fitted for the response category. Other models, based upon the combined responses of all categories except DNT, and based upon all 2-factor interaction terms, were tested and then discarded because they were not informative. Based on the fitted models, significance of the model terms and odds ratios for pairwise comparisons was evaluated.

Model with continuous and categorical variables: We constructed models using continuous morphometric dimensions in place of the categorical variables turtle size and hook size to enable the user theoretically to predict the odds of a serious injury based on a given turtle size or hook width within a given range. Only the 
ATS response category was considered in this model. We considered head width and $\mathrm{SCL}_{\text {std }}$ in place of the categorical variable turtle size class, but these 2 continuous variables were highly correlated $\left(n=30, r^{2}=0.98\right.$, $\mathrm{p}<0.0001)$, implying need for only one. $\mathrm{SCL}_{\text {std }}$ was chosen for the analysis, as it is the most commonly obtained measure in the field. It is important to note that these relationships only apply to loggerheads, as other cheloniids do not have comparable cranial allometry.

We chose the continuous variable minimum measured hook width $(14 / 0,35.7 \mathrm{~mm} ; 16 / 0,46.0 \mathrm{~mm} ; 18 / 0$, $51.3 \mathrm{~mm}$; and $20 / 0 ; 62.1 \mathrm{~mm}$ ) in place of the categorical variable nominal hook size as the dimension most relevant to swallowing potential.

Multinomial logistic regression model. The probability of turtle response falling into each of the 4 response categories (DNT, PIM, FIM, ATS) due to various combinations of turtle size class $\left(45,55,65 \mathrm{~cm} \mathrm{SCL}_{\text {std }}\right)$, hook size $(14 / 0,16 / 0,18 / 0,20 / 0)$, bait type (sardine, squid), and baiting technique (single, threaded) was estimated through fitting of a multinomial logistic regression model with these categorical terms as independent variables.

\section{RESULTS}

In the trials, the turtles often used their front flippers to manipulate the bait into a position where it could be eaten easily. They approached and ingested the squid and sardine baits differently. The turtles usually approached the squid from the anterior end at the tentacles, taking the entire squid in 1 or 2 bites, usually intact. They approached the sardines from the middle as often as from the tail end, and generally tore off pieces or stripped the entire sardine from the hook.

The analysis results reported for the categorical variable model and the continuous and categorical variable model focus on the ATS category; this category was the focus of our interest as it has the potential to be the most serious interaction of concern. Summary results providing the number of turtles coded in each response category from every trial are given in Tables S1-S3 in the supplement at www.int-res.com/ articles/suppl/n014p001_supp.pdf. Results from the multinomial logistic regression model are presented for all 4 response categories.

\section{Categorical variable model}

All logistic regression model terms in the categorical variable model were significant for the ATS category, most with $\mathrm{p}<0.0001$ (Table 1 ). The odds ratio estimate for turtle size indicates that with any combi- nation of other factors (hook size, bait type, and baiting technique), the odds of the $65 \mathrm{~cm}$ turtles attempting to swallow were 20 times greater than for the $45 \mathrm{~cm}$ turtles, but only 1.5 times higher than for the $55 \mathrm{~cm}$ turtles. The odds of a $55 \mathrm{~cm}$ turtle attempting to swallow were 13 times higher than for the $45 \mathrm{~cm}$ turtles. The odds ratios for hook size indicate that the odds that the turtles would attempt to swallow smaller hooks were substantially higher than for larger hooks, with smaller differences for hooks of similar sizes (e.g. 16 versus 18 and 14 versus 16). At any combination of turtle size, bait type, and baiting technique, the odds of a turtle attempting to swallow a 14/0 hook were 97 times greater than for a 20/0 hook, 11 times greater than for an 18/0 hook, and 3 times greater than for a 16/0 hook. The odds of a turtle attempting to swallow a 16/0 hook were 32 times greater than for a 20/0 hook, and 3.6 times greater than for an 18/0 hook. The odds of a turtle attempting to swallow an 18/0 hook were 9 times greater than for a 20/0 hook. The odds of attempting to swallow squid were $\sim 4$ times greater than for sardines at any combination of turtle size, bait type, and baiting technique. The odds of attempting to swallow threaded baits were $\sim 2.5$ times greater than for single-baited hooks (Table 1).

\section{Continuous and categorical variable model}

In the model with continuous and categorical variables, all logistic regression model terms were signifi-

Table 1. Caretta caretta. Odds ratio estimates and associated $95 \%$ confidence intervals (CI) for the category 'attempt to swallow' from the logistic regression model $(n=882)$ with categorical terms of turtle size $(45,55$, and $65 \mathrm{~cm}$ mean standard straight carapace length), hook size $(14 / 0,16 / 0,18 / 0$, and $20 / 0$ ), bait type (sardine or squid), and baiting style (single or threaded). See Fig. 1 for hook sizes in mm. p $<0.05$ was considered statistically significant

\begin{tabular}{|lrrrr|}
\hline Effect & $\begin{array}{c}\text { Odds } \\
\text { ratio }\end{array}$ & $\begin{array}{c}\text { Lower } \\
95 \% \text { CI }\end{array}$ & $\begin{array}{r}\text { Upper } \\
95 \% \text { CI }\end{array}$ & p \\
& & & & \\
\hline Turtle size: 45 vs. 65 & 0.049 & 0.027 & 0.087 & $<0.0001$ \\
Turtle size: 55 vs. 65 & 0.639 & 0.426 & 0.958 & 0.0302 \\
Turtle size: 45 vs. 55 & 0.076 & 0.044 & 0.134 & $<0.0001$ \\
Hook: $14 / 0$ vs. $20 / 0$ & 97.541 & 40.866 & 232.812 & $<0.0001$ \\
Hook: $16 / 0$ vs. $20 / 0$ & 32.006 & 13.733 & 74.594 & $<0.0001$ \\
Hook: $18 / 0$ vs. $20 / 0$ & 8.781 & 3.735 & 20.646 & $<0.0001$ \\
Hook: $14 / 0$ vs. $18 / 0$ & 11.108 & 6.636 & 18.594 & $<0.0001$ \\
Hook: $16 / 0$ vs. 18/0 & 3.645 & 2.236 & 5.941 & $<0.0001$ \\
Hook: $14 / 0$ vs. $16 / 0$ & 3.048 & 1.935 & 4.799 & $<0.0001$ \\
Bait: sardine vs. squid & 0.247 & 0.167 & 0.365 & $<0.0001$ \\
Style: single vs. & 0.399 & 0.274 & 0.582 & $<0.0001$ \\
threaded & & & & \\
\hline
\end{tabular}


cant, each with $\mathrm{p}<0.0001$ (Table 2). The odds of turtles attempting to swallow squid were $\sim 4$ times greater than for sardines. The odds of turtles attempting to swallow threaded baits were $\sim 2.4$ times greater than for single baited hooks. Note that these results are fairly consistent for both the models.

Based on the fitted models, the odds ratio due to an increase of $k$ units in the continuous variables (turtle size in $\mathrm{cm} \mathrm{SCL}_{\text {std }}$ and minimum hook width in $\mathrm{mm}$ ) can be computed. The odds ratios for an increase of $k$ $\mathrm{cm}$ in $\mathrm{SCL}_{\text {std }}$ is given by $(1.161)^{k}$, where $k$ represents an increase in $\mathrm{SCL}_{\text {std }}$ in $\mathrm{cm}$ (Fig. 2). The odds ratio increased with increasing $\mathrm{SCL}_{\text {std }}$ as expected. The odds ratios for the increase of $k \mathrm{~mm}$ in hook size (minimum hook width) is given by $(0.853)^{k}$, where $k$ represents an increase in hook size in mm (Fig. 3). The odds ratio decreased with increasing hook size, as expected.

Table 2. Caretta caretta. Odds ratio estimates and associated $95 \%$ confidence intervals (CI) for the category 'attempt to swallow' from the logistic regression model $(n=882)$ with continuous terms of turtle size (standard straight carapace length in $\left.\mathrm{cm}_{1} \mathrm{SCL}_{\text {std }}\right)$ and hook size $(14 / 0,16 / 0,18 / 0$ and $20 / 0$ ), and categorical terms of bait type (sardine or squid) and baiting style (single or threaded). See Fig. 1 for hook sizes in mm. $\mathrm{p}<0.05$ was considered to be statistically significant

\begin{tabular}{|lcccc|}
\hline Effect & $\begin{array}{c}\text { Odds } \\
\text { ratio }\end{array}$ & $\begin{array}{c}\text { Lower } \\
95 \% \text { CI }\end{array}$ & $\begin{array}{c}\text { Upper } \\
95 \% \text { CI }\end{array}$ & $p$ \\
\hline SCL $_{\text {std }}$ & 1.161 & 1.129 & 1.194 & $<0.0001$ \\
$\begin{array}{l}\text { Hook size } \\
\begin{array}{l}\text { Bait type } \\
\text { (sardine vs. squid) }\end{array}\end{array}$ & 0.853 & 0.832 & 0.874 & $<0.0001$ \\
$\begin{array}{l}\text { Bait style } \\
\text { (single vs. threaded) }\end{array}$ & 0.423 & 0.175 & 0.376 & $<0.0001$ \\
\hline
\end{tabular}

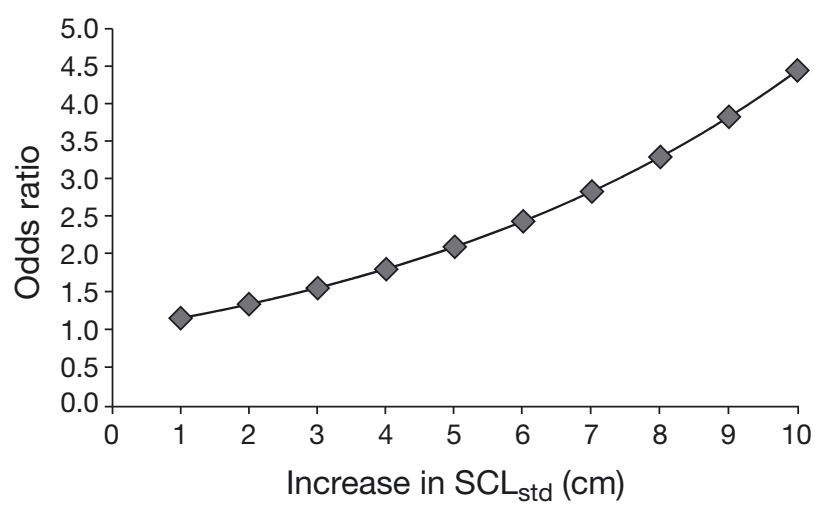

Fig. 2. Caretta caretta. Odds ratio estimates from the model with the continuous variable predicting that odds ratios for attempting to swallow (ATS) increase as turtle size (mean standard straight carapace length, $\mathrm{SCL}_{\text {std }}$ ) increases. The odds ratios for the ATS category for an increase of $\mathrm{k} \mathrm{cm}$ in $\mathrm{SCL}_{\text {std }}$ is given by $(1.161)^{k}$

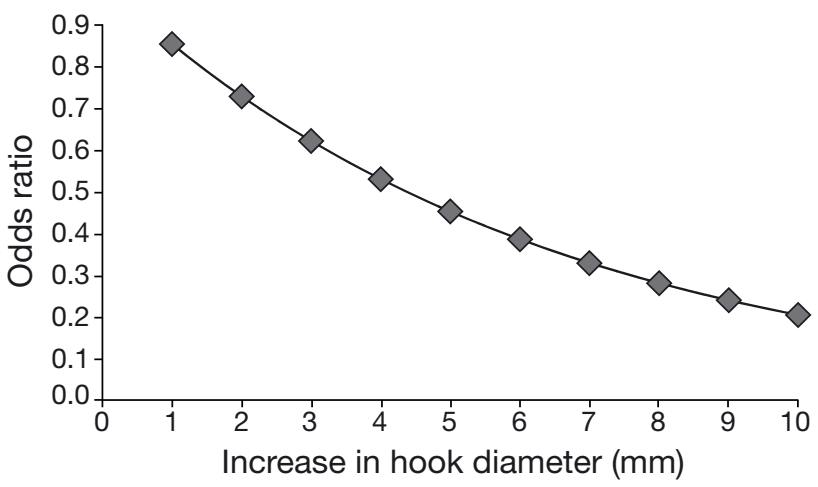

Fig. 3. Caretta caretta. Odds ratio estimates from the model with the continuous variable predicting that odds ratios for attempting to swallow (ATS) decrease as hook width increases. The odds ratios for the ATS category for an increase of $k \mathrm{~mm}$ in hook size (minimum hook width) is given by $(0.853)^{k}$

\section{Multinomial logistic regression model}

The predicted probability for each response category (DNT, PIM, FIM, and ATS) for each size class from the multinomial logistic regression model $(n=882)$ with terms of turtle size $\left(\mathrm{SCL}_{\mathrm{std}}\right)$, hook size, bait type (sardine or squid), and baiting style (single or threaded) are given in Tables $\mathrm{S} 4-\mathrm{S} 6$ in the supplement at www.int-res.com/articles/suppl/n014p001_supp.pdf.

The overall model fit and each of the model terms were highly significant (each with $\mathrm{p}<0.0001$ ).

The probability of a turtle not taking the hook into the mouth (DNT) decreased with increasing turtle size (Fig. 4). The probability of a turtle taking the hook partially into the mouth (PIM) increased as hook size increased for the 55 and $65 \mathrm{~cm}$ size classes (Fig. 5). There was a low probability of 55 and $65 \mathrm{~cm}$ turtles taking the hook fully into the mouth (FIM, Fig. 6). The probability of turtles attempting to swallow hooks (ATS) decreased with increasing hook size, as expected (Fig. 7). The predicted probability of a turtle attempting to swallow squid was greater than with sardines and greater with threaded baits than single baits within each hook size (Fig. 7). The results from the 55 and $65 \mathrm{~cm}$ size classes were similar for all response categories.

\section{DISCUSSION}

The most effective mitigation measures to reduce mortality in pelagic longline fisheries likely will vary across species, populations, geographical regions, and fisheries. However, the research presented here can serve as a basis for establishing inexpensive and logistically feasible mitigation measures to reduce sea turtle mortality. We do not propose that these trials mimic ac- 

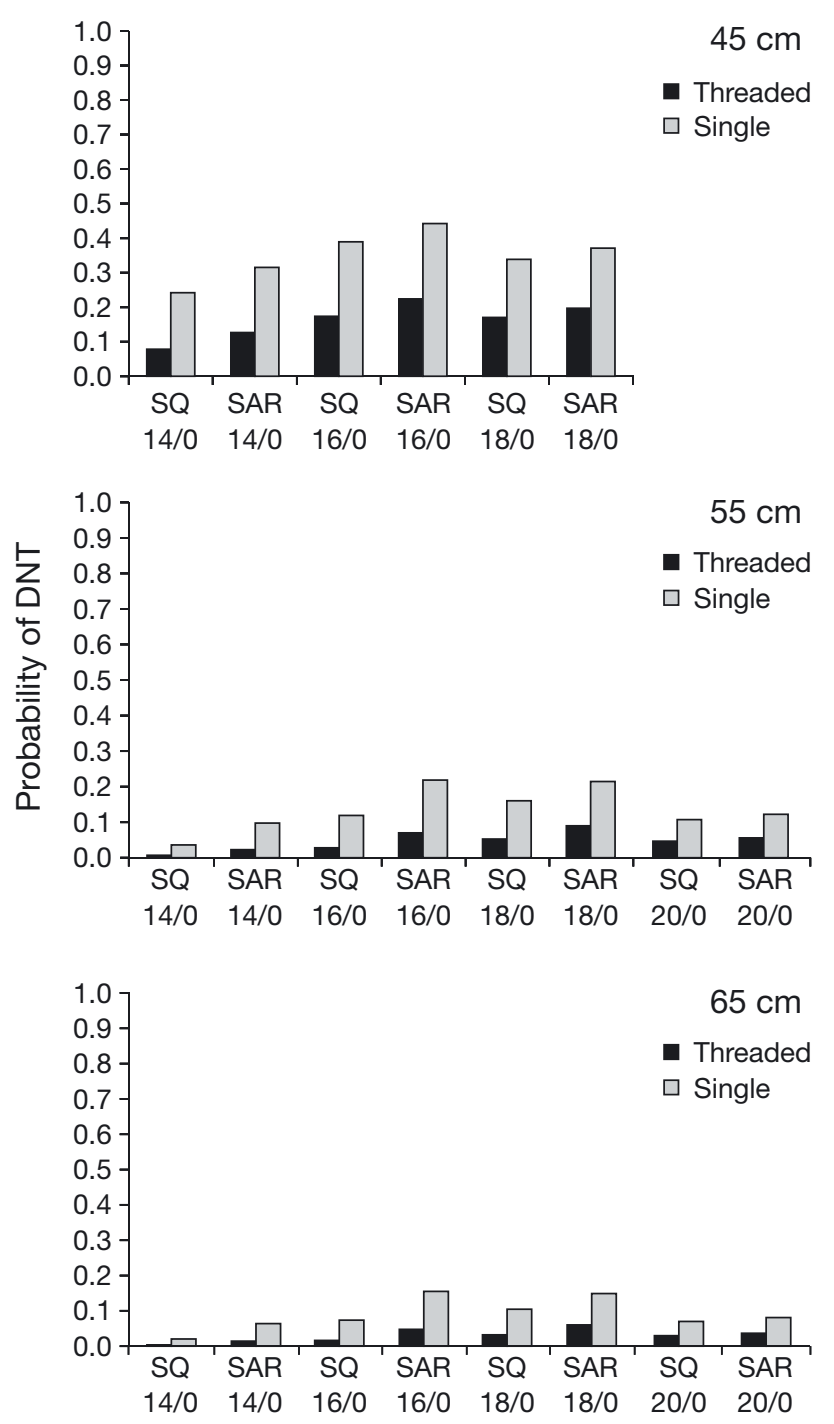

Fig. 4. Caretta caretta. Probability of 45, 55, and $65 \mathrm{~cm}$ (mean standard straight carapace length, $\mathrm{SCL}_{\text {std }}$ ) size class turtles that 'did not take' (DNT) 14/0, 16/0, 18/0, and 20/0 (see Fig. 1 for mm equivalents) hooks baited (threaded and single baiting technique) with squid (SQ) or sardines (SAR). The 20/0 hooks were not tested with the $45 \mathrm{~cm}$ size class

tual fishing conditions, but rather that they incorporate a consistent method for studying the feeding process dynamics under controlled circumstances. Target species retention is another important factor to consider, but this is beyond the scope of the present study.

Persistence during foraging may increase the probability that a turtle will be incidentally hooked on hook and line gear. Few observations are available for wild foraging loggerheads, but it appears that they feed in an opportunistic and deliberate manner. Loggerheads in neritic environments have been observed persistently mining for bivalves in the sand for up to $30 \mathrm{~min}$ (Schofield et al. 2006). In pelagic environments, log-
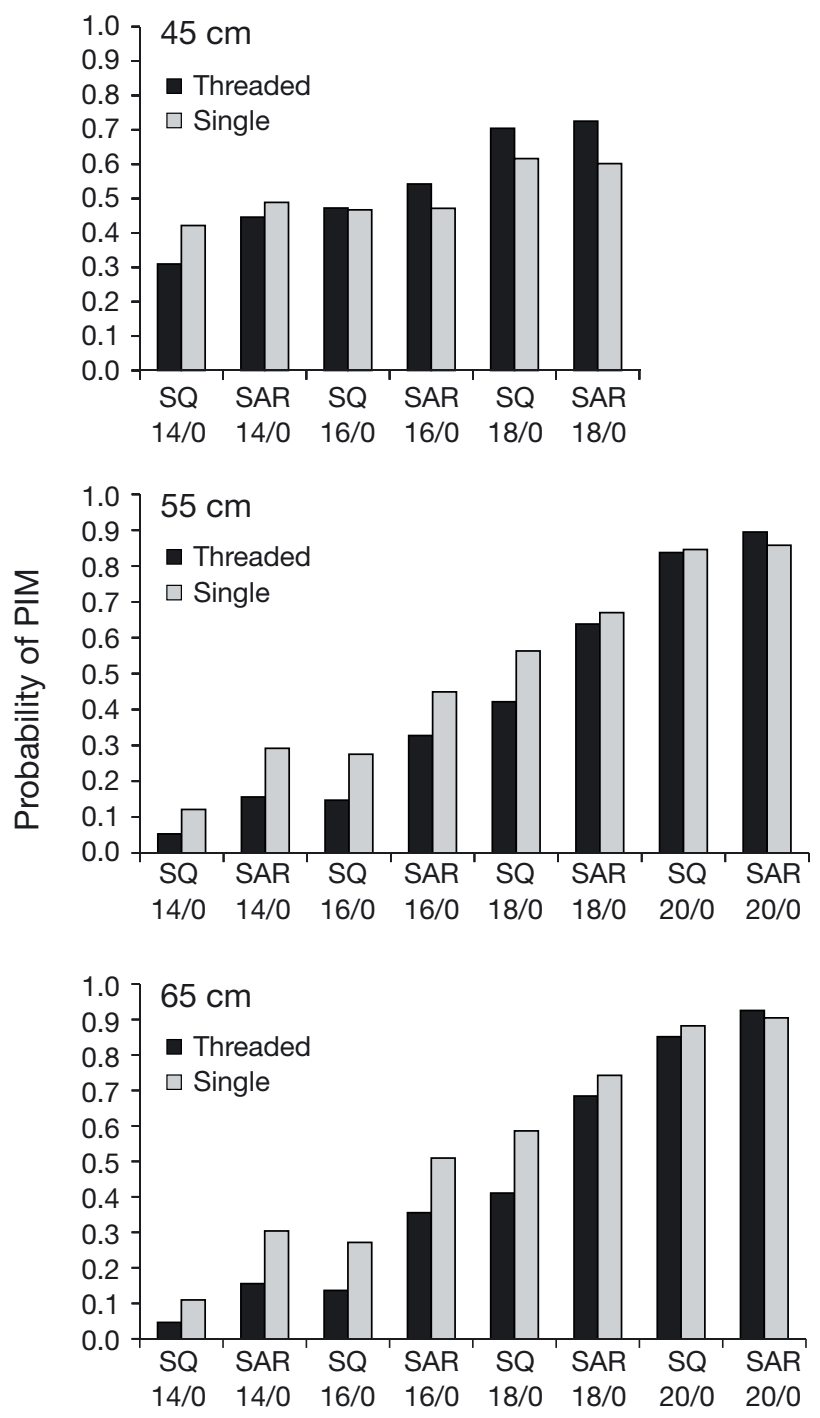

Fig. 5. Caretta caretta. Probability of 45, 55, and $65 \mathrm{~cm}$ (mean standard straight carapace length, $\mathrm{SCL}_{\text {std }}$ ) size class turtles in response category 'partially in mouth' (PIM) with 14/0, 16/0, 18/0, and 20/0 (see Fig. 1 for mm equivalents) hooks baited (threaded and single baiting technique) with squid (SQ) or sardines (SAR). The 20/0 hooks were not tested with the $45 \mathrm{~cm}$ size class

gerheads have a shallow dive distribution, associating with convergence zones (Polovina et al. 2004) and feeding opportunistically on floating organisms, such as coelenterates, and organisms riding on floating objects in the Pacific (Parker et al. 2005) and the Atlantic (Van Nierop \& den Hartog 1984).

How these controlled laboratory trials relate to wild feeding behavior of loggerhead turtles during an incidental capture is unknown, but the mechanics of bait texture and shielding effects likely are similar. We did not observe any relationship between hook size and bait retention, as the bait was not stripped more easily 

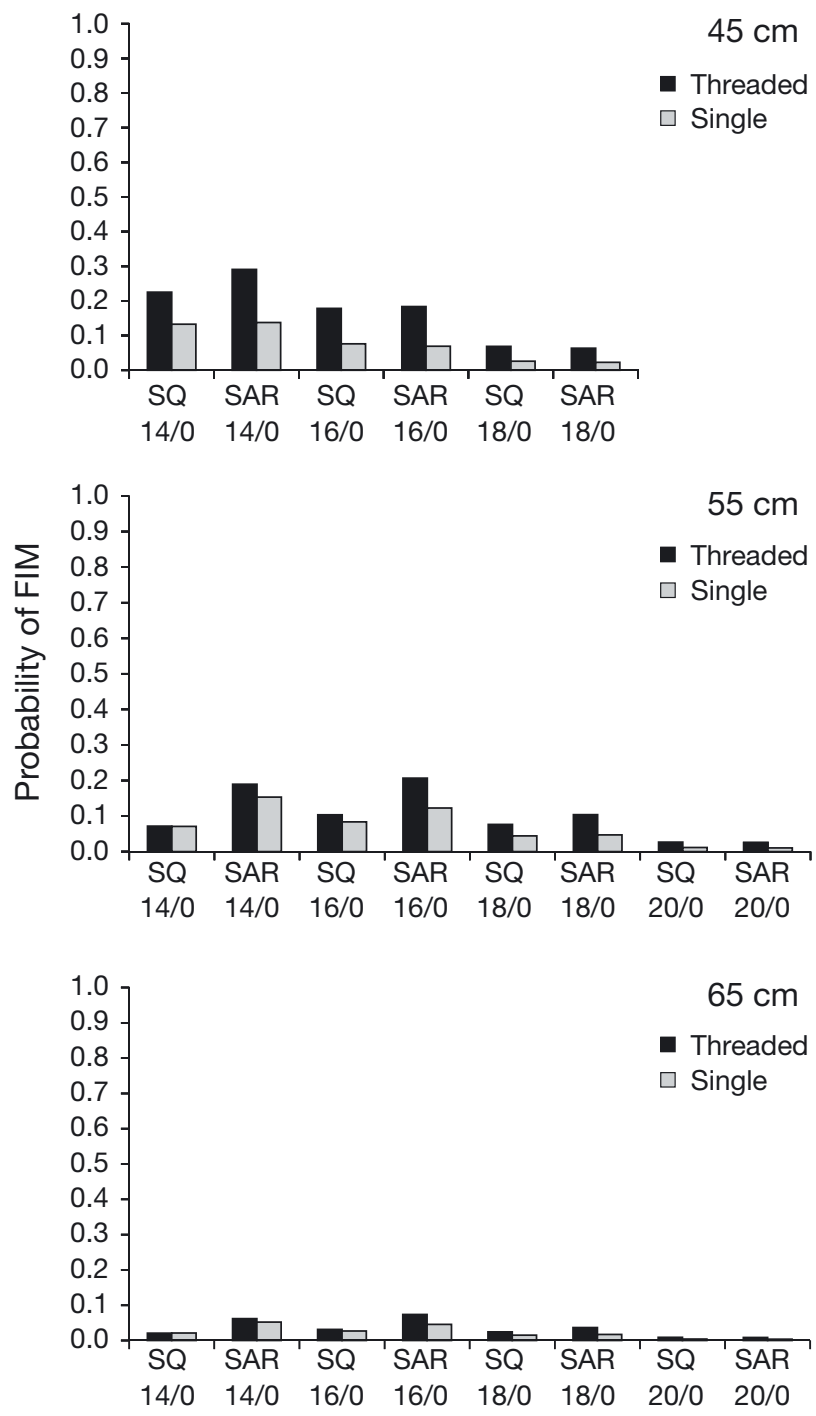

Fig. 6. Caretta caretta. Probability of 45, 55, and $65 \mathrm{~cm}$ (mean standard straight carapace length, $\mathrm{SCL}_{\text {std }}$ ) size class turtles in response category 'fully in mouth' (FIM) with 14/0, 16/0, 18/0, and 20/0 (see Fig. 1 for $\mathrm{mm}$ equivalents) hooks baited (threaded and single baiting technique) with squid (SQ) or sardines (SAR). The 20/0 hooks were not tested with the $45 \mathrm{~cm}$ size class

from either larger or smaller hooks. The size of the turtle also did not seem to be a factor in the turtles' ability to remove bait from the hook; each size class seemed equally persistent and able to tear bait from the hooks. A turtle's odds of ingesting hooks may be influenced by differences in bait texture, hook shielding effects, and behavioral differences in how individual turtles respond to different hook/bait combinations. The results from the 55 and $65 \mathrm{~cm}$ size classes were similar for all response categories, suggesting that loggerheads $\geq 55 \mathrm{~cm}$ SCL may have similar potential to ingest hooks in this size range (14/0 to $20 / 0)$.
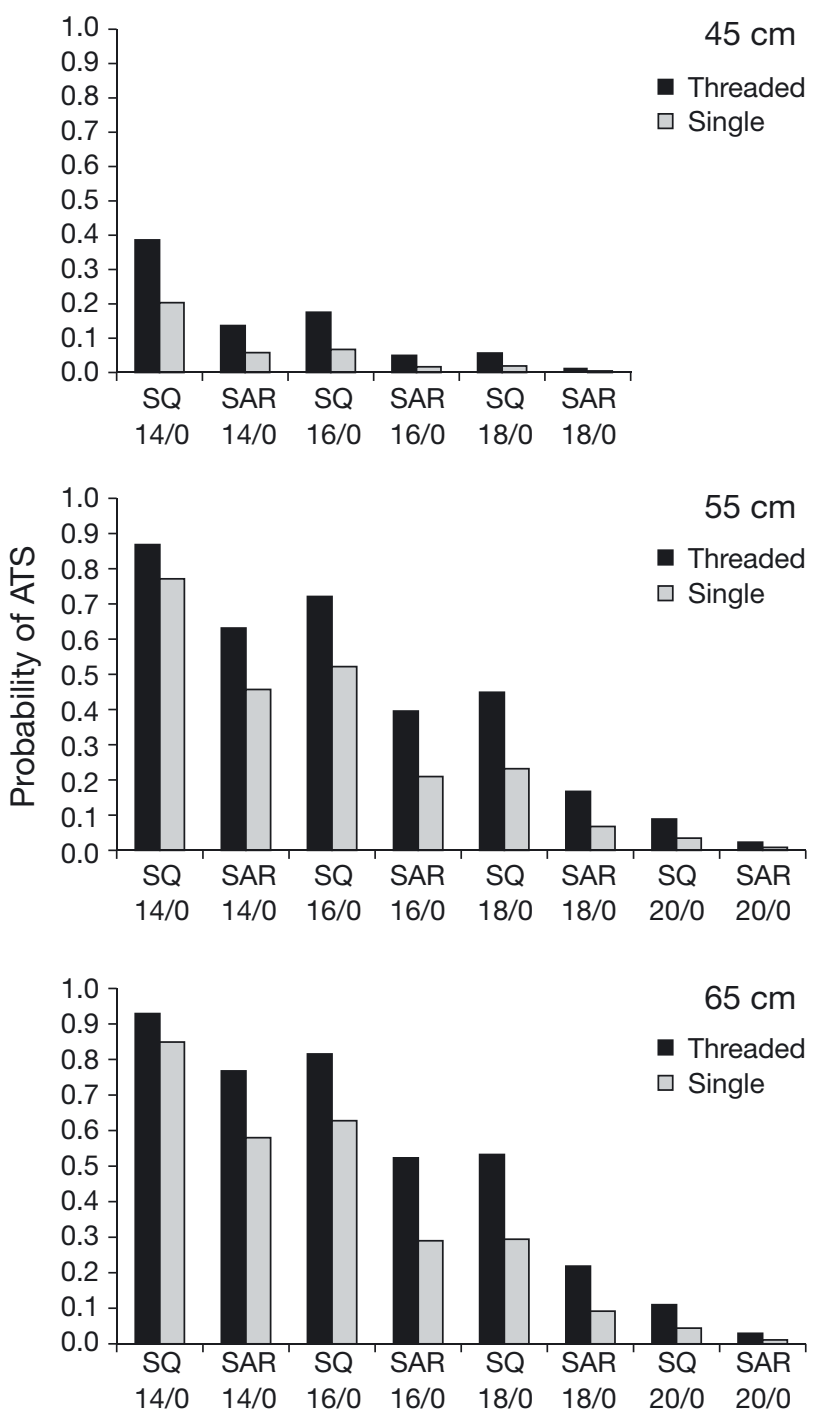

Fig. 7. Caretta caretta. Probability of 45, 55, and $65 \mathrm{~cm}$ (mean standard straight carapace length, $\left(\mathrm{SCL}_{\mathrm{std}}\right)$ size class turtles that 'attempted to swallow' (ATS) 14/0, 16/0, 18/0, and 20/0 (see Fig. 1 for $\mathrm{mm}$ equivalents) hooks baited (threaded and single baiting technique) with squid (SQ) or sardines (SAR). The 20/0 hooks were not tested with the $45 \mathrm{~cm}$ size class

As discussed in the 'Results', the turtles approached and fed upon the bait types differently. In the case of sardines it was easier for the turtles to tear pieces off or to strip the fish from the hook entirely. The texture of the squid made it more difficult to tear than the fish, and they tended to ingest the squid whole. The squid often shielded the hook until the turtle had already ingested it. Turtles might have been better able to see or feel the hook when it was baited with sardines, and they sometimes actively avoided the hooks when they touched the metal. We believe that other types of whole finfish likely would yield similar results. Threaded baits, particularly sardines, appeared 
slightly more difficult to strip from the hook because the bait was fastened more securely to the hook, although there was not a significant interaction between bait type and baiting technique. Fishers choose their baiting technique based on a variety of factors, including the importance of bait retention versus speed of baiting the hooks, hook offset, and past results. Factors such as target species retention, bait condition, and time can all play a role in these decisions. Although baiting technique could be regulated, enforcement might be difficult or controversial.

Hook size, bait type, and feeding behavior may affect the location where the turtles are hooked, which could have implications for turtle survival during actual fishery interactions. However, because the hooks in this study were modified and not actually swallowed during the trials, the significance of an ATS response must be interpreted with caution when assessing actual injury risk during normal fishing operations. Studies with fish (Prince et al. 2002, Skomal et al. 2002) and sea turtles (Watson et al. 2005) have shown that circle hooks are more likely to hook animals in the jaw than in the esophagus when compared with 'J' style hooks, potentially causing less injury and facilitating easier gear removal. Therefore, hooking locations and mortality rates may differ among different hook types. Furthermore, due to the circle hook design, the barb of a circle hook may not embed even when the hook is swallowed, potentially improving the chance that a hook will pass through the gut or be removed with minimal injury to the turtle.

Turtles that showed the ATS response likely would have swallowed the baited hooks if allowed, and hooking location and degree of gear removal may affect post-hooking mortality risk (Ryder et al. 2006). Necropsies conducted on longline-captured loggerheads demonstrated that ingested hooks can cause death as a result of traumatic perforation to the heart, blood vessels, or gastrointestinal tract, or ulcerative and fibrinous esophagitis (Orós et al. 2005, Valente et al. 2007, Casale et al. 2008). In many cases, ingested hooks kill turtles within a short time period, but in other cases, the hooks lead to secondary infections and impaired digestive functions that result in a later second mortality peak (Chaloupka et al. 2004, Casale et al. 2008). Dead stranded turtles have a higher proportion of deeply ingested hooks than hooks in the upper esophagus; similarly, live turtles found stranded are more likely to die if they are injured by deeply ingested hooks (Aguilar et al. 1995, Casale et al. 2008). Results from satellite telemetry research are generally consistent with the hypothesis that deeply hooked turtles are more likely to die than are lightly hooked or control turtles, particularly within $90 \mathrm{~d}$ of release (Chaloupka et al. 2004). Furthermore, research indi- cates that when all gear is removed from lightly hooked turtles, there is no detectable increase in mortality compared to controls (Swimmer et al. 2006, Sasso \& Epperly 2007); research has not been conducted on mortality of lightly hooked turtles released with gear remaining.

Line removal may be more difficult when hooks are deeply ingested than when they are present in the mouth or beak. Even short lengths of line $(34 \mathrm{~cm}$, Bjorndal et al. 1994; 52 cm, Casale et al. 2008) ingested can be lethal as a result of gut strangulation. These effects occur when peristaltic movement displaces the line and produces folding or intussusception from the point where the hook is embedded, disabling digestive functions and ultimately causing starvation (Orós et al. 2005, Valente et al. 2007, Casale et al. 2008).

Thus, it is important to maximize gear removal by using careful release tools and techniques (see NMFS SEFSC 2008) to minimize injury, but these efforts alone cannot eliminate fishery-induced mortality. Hooks that have been deeply ingested, where the insertion point of the barb is not visible, cannot be safely removed without potentially causing further injury (NMFS SEFSC 2008). In these instances, it is likely that the line will be cut, with several $\mathrm{cm}$ or more of line remaining. Given what we know about the effects of such injuries, the development of new measures to prevent deep ingestion of hooks and line, and to reduce overall capture rates, should be a priority.

Our results indicate that for 3 size classes of loggerheads, using a larger hook may reduce the chance of swallowing the hook. However, this may not be a tenable solution in fisheries where using larger hooks would result in an economically significant reduction in target catch. Larger hooks also might be ineffective at preventing the capture of larger size classes of loggerhead turtles, considered to be of the highest reproductive importance to the population (Crouse et al. 1987, Heppell 1998, Wallace et al. 2008), or leatherbacks, which might be at greater risk of foul-hooking with larger hooks. Thus, bait type and possibly baiting technique, alone or in combination with larger hooks, may also be important factors in minimizing serious injury.

\section{CONCLUSIONS}

Successful bycatch solutions will require a fisheryspecific approach, in which regional differences among target catch, fishing gear and techniques, and sea turtle size class and species composition are considered before devising the most effective solutions. In conjunction with reducing the overall incidental capture rates of sea turtles in fishery interactions, using solutions such as reducing temporal and spatial over- 
lap or changing hook type from $\mathrm{J}$ to circle (Watson et al. 2005, Gilman et al. 2006, Read 2007) may reduce incidental mortality. Affecting hooking location and maximizing gear removal potential may reduce the severity of the interactions.

The results presented here further clarify the effect of hook size and bait type on ingestion rates for loggerhead sea turtles. These trials suggest that the ingestion rate of hooks is a function of hook size relative to the size class of turtles, bait type, and to a lesser extent, baiting technique. They clearly demonstrate the advantage of larger hook size on reducing deep ingestion rates. Whole sardines greatly decreased the incidence of potential swallowing when compared with whole squid. Larger hooks baited with whole finfish may pose less risk for serious injury or mortality from deep ingestion than smaller hooks baited with squid.

Acknowledgements. We gratefully acknowledge the assistance of L. Belskis, M. Burgos, C. Bustinza, D. Foster, J. Gearhart, S. Kethan, M. Rodriguez, L. Saxon, and W. Teas. We thank J. Bohnsack, A. Chester, M. Salmon, and the anonymous reviewers for providing helpful comments. The turtles were collected as hatchlings under the authority of Florida Fish and Wildlife Conservation Commission (FFWCC) Marine Turtle Permit no. 015, held under the authority of the United States Fish and Wildlife Service (USFWS) Permit no. TE676379-4, and tested under the authority of FFWCC Marine Turtle Permit no. 030. All work was done in compliance with institutional, national, and international guidelines concerning the use of animals in research, including threatened and/or endangered species, as well as all handling requirements under these permits.

\section{LITERATURE CITED}

Aguilar R, Mas J, Pastor X (1995) Impact of Spanish swordfish longline fisheries on the loggerhead sea turtle Caretta caretta in the western Mediterranean. In: Richardson JI, Richardson TH (compilers) Proc 12th Annu Workshop Sea Turtle Biol Conserv. National Oceanic and Atmospheric Administration (NOAA) Tech Memo NMFS-SEFSC-361, p 1-6

Beerkircher LR, Brown CJ, Abercrombie DL, Lee DW (2004) SEFSC pelagic observer program data summary for 19922002. NOAA Tech Memo NMFS-SEFSC-522, p 11-12

Bjorndal KA, Bolten AB, Lagueux CJ (1994) Ingestion of marine debris by juvenile sea turtles in coastal Florida habitats. Mar Pollut Bull 28:154-158

Bjorndal KA, Bolten AB, Martins HR (2000) Somatic growth model of juvenile loggerhead sea turtles Caretta caretta: duration of pelagic stage. Mar Ecol Prog Ser 202: 265-272

Boggs CH (2004) Hawaii fishing experiments to reduce pelagic longline bycatch of sea turtles. In: Long KJ, Schroeder BA (eds) Proc Int Technical Expert Workshop on Marine Turtle Bycatch in Longline Fisheries. NOAA Tech Memo NMFS-OPR-26, p 121-138

Bolten AB (1999) Techniques for measuring sea turtles. In: Eckert KL, Bjorndal KA, Abreu-Grobois FA, Donnelly M (eds) Research and management techniques for the con- servation of sea turtles. IUCN/SSC Marine Turtle Specialist Group, Publication No. 4, Consolidated Graphic Communications, Blanchard, PA, p 110-114

Bolten AB, Bjorndal KA (2005) Experiment to evaluate gear modification on rates of sea turtle bycatch in the swordfish longline fishery in the Azores - Phase 4. Final report to NMFS SEFSC. NOAA award number NA03NMF4540204, Miami, FL, p 1-21

Camiñas JA (1997) Capturas accidentales de tortuga boba Caretta caretta (Linnaeus, 1758) en el Mediterráneo occidental en la pesquería de palangre de superficie de pez espada (Xiphias gladius L.). Coll Vol Sci Pap ICCAT 4: $446-455$

Camiñas JA (2004) Sea turtles of the Mediterranean Sea: population dynamics, sources of mortality and relative importance of fisheries impacts. Expert consultation on interactions between sea turtles and fisheries within an ecosystem context. Food and Agriculture Organization Fish Rep 738 (Suppl). FAO, Rome, p 27-84

> Casale P, Freggi D, Rocco M (2008) Mortality induced by drifting longline hooks and branchlines in loggerhead sea turtles, estimated through observation in captivity. Aquat Conserv 18:945-954

Chaloupka M, Parker D, Balazs G (2004) Modeling postrelease mortality of loggerhead sea turtles exposed to the Hawaii-based pelagic longline fishery. Mar Ecol Prog Ser 280:285-293

Crouse DT, Crowder LG, Caswell H (1987) A stage-based population model for loggerhead sea turtles and implications for conservation. Ecology 68:1412-1423

Gilman E, Zollett E, Beverly S, Nakano H and others (2006) Reducing sea turtle by-catch in pelagic longline fisheries. Fish Fish 7:1-22

Hall M (2006) Description of sea turtle bycatch mitigation program for the coastal longline fleets and preliminary results of circle hook experiments. Working Group on Stock Assessment 7th Meeting, Southwest Fisheries Science Center, La Jolla, CA, 15-19 May 2006. Inter-American Tropical Tuna Commission Document SAR-7-08

Hall M, Mituhasi T, Vogel N, Lennert-Cody C, Mug M (2008) Bycatch reduction in the artisanal longline fleets of the eastern Pacific 2004-2008. Inter-American Tropical Tuna Commission, La Jolla, CA, p 20-47

Hamann M, Godfrey MH, Seminoff JA, Arthur K and others (2010) Global research priorities for sea turtles: informing management and conservation in the 21st century. Endang Species Res 11:245-269

> Heppell SS (1998) An application of life history theory and population model analysis to turtle conservation. Copeia 1998:367-375

Higgins B (2003) Sea turtle husbandry. In: Lutz PL, Musick JA, Wyneken J (eds) The biology of sea turtles, Vol II. CRC Press, Boca Raton, FL, p 411-440

Hillestad HO, Richardson JI, McVea C, Watson JM (1995) Worldwide incidental capture of sea turtles. In: Bjorndal KA (ed) Biology and conservation of sea turtles, revised edn. Smithsonian Institution Press, Washington, DC, p 489-495

IUCN (International Union for Conservation of Nature) (2009) IUCN Red List of Threatened Species, Version 2009.1. Available at www.iucnredlist.org

Jribi I, Echwikhi K, Bradai MN, Bouain A (2008) Incidental capture of sea turtles by longlines in the Gulf of Gabés (south Tunisia): a comparative study between bottom and surface longlines. Sci Mar 72:337-342

> Lewison RL, Crowder LB (2007) Putting longline bycatch of sea turtles into perspective. Conserv Biol 21:79-86 
Lewison RL, Freeman SA, Crowder LB (2004) Quantifying the effects of fisheries on threatened species: the impact of pelagic longlines on loggerhead and leatherback sea turtles. Ecol Lett 7:221-231

Lohmann KJ, Wang JH, Boles LC, McAlister J, Higgins B, Lohmann CMF (2006) Development of turtle-safe light sticks for use in longline fisheries. In: Swimmer Y, Brill RW (eds) Sea turtle and pelagic fish sensory biology: developing techniques to reduce sea turtle bycatch in longline fisheries. NOAA Tech Memo NMFS-PIFSC-7, p 65-76

Lutcavage ME, Plotkin P, Witherington B, Lutz P (1997) Human impacts on sea turtle survival. In: Lutz PL, Musick JA (eds) The biology of sea turtles. CRC Press, Boca Raton, FL, p 388-404

NMFS (National Marine Fisheries Service) (2001) Biological opinion of the reinitiation of consultation on the Atlantic highly migratory 7 species fishery management plan and its associated fisheries. NMFS, Silver Springs, MD

NMFS SEFSC (Southeast Fisheries Science Center) (2008) Careful release protocols for sea turtle release with minimal injury. NOAA Tech Memo NMFS-SEFSC-580

Orós J, Torrent A, Calabuig P, Déniz S (2005) Diseases and causes of mortality among sea turtles stranded in the Canary Islands, Spain (1998-2001). Dis Aquat Org 63: 13-24

Parker DM, Cooke W, Balazs GH (2005) Diet of oceanic loggerhead sea turtles (Caretta caretta) in the central North Pacific. Fish Bull 103:142-152

Polovina JJ, Balazs GH, Howell EA, Parker DM, Seki MP, Dutton PH (2004) Forage and migration habitat of loggerhead (Caretta caretta) and olive ridley (Lepidochelys olivacea) sea turtles in the central North Pacific Ocean. Fish Oceanogr 13:36-51

Prince ED, Ortiz M, Venizelos A (2002) A comparison of circle hook and ' $\mathrm{J}$ ' hook performance in recreational catch-andrelease fisheries for billfish. Am Fish Soc Symp 30:66-79

Read AJ (2007) Do circle hooks reduce the mortality of sea turtles in pelagic longlines? A review of recent experiments. Biol Conserv 135:155-169

Ryder CE, Conant TA, Schroeder BA (2006) Report of the workshop on marine turtle longline post-interaction mortality, Bethesda, MD, USA, 15-16 January 2004. USDOC NOAA Tech Memo NMFS-OPR-29, p 1-28

Sasso CR, Epperly SP (2007) Survival of pelagic juvenile loggerhead turtles in the open ocean. J Wildl Manag 71: 1830-1835

Schofield G, Katselidis KA, Dimopoulos P, Pantis JD, Hays GC (2006) Behaviour analysis of the loggerhead sea turtle Caretta caretta from direct in-water observation. Endang Species Res 2:71-79

Skomal GB, Chase BC, Prince ED (2002) A comparison of circle hook and straight hook performance in recreational fisheries for juvenile bluefin tuna. Am Fish Soc Symp 30: 57-65

Snover ML (2002) Growth and ontogeny of sea turtles using skeletochronology: methods, validation, and applications to conservation. $\mathrm{PhD}$ dissertation, Duke University, Durham, NC

Editorial responsibility: Mark Hamann, Townsville, Queensland, Australia
Swimmer Y, Arauz R, McCracken M, McNaughton L and others (2006) Diving behavior and delayed mortality of olive ridley sea turtles Lepidochelys olivacea after their release from longline fishing gear. Mar Ecol Prog Ser 323: $253-261$

USDOC (US Department of Commerce) (1999) Western Pacific pelagic fisheries; Hawaii-based pelagic longline area closure. Fed Regist 64:72290-72291

USDOC (2000a) Atlantic highly migratory species: pelagic longline fishery; sea turtle protection measures. Fed Regist 65:60889-60892

USDOC (2000b) Fisheries off west coast states and in the western Pacific: western Pacific pelagic fisheries; Hawaiibased pelagic longline area closure. Fed Regist 65: 51992-51996

USDOC (2001a) Atlantic highly migratory species: pelagic longline fishery; sea turtle protection measures. Fed Regist 66:36711-36714

USDOC (2001b) Atlantic highly migratory species: pelagic longline fishery; sea turtle protection measures. Fed Regist 66:64378-64379

USDOC (2004a) Fisheries off west coast states and in the western Pacific; western Pacific pelagic fisheries; pelagic longline fishing restrictions, seasonal area closure, limit on swordfish fishing effort, gear restrictions, and other sea turtle take mitigation measures. Fed Regist 69: 17329-17354

USDOC (2004b) Atlantic highly migratory species (HMS) pelagic longline fishery; final rule. Fed Regist 69: 40734-40758

Valente ALS, Parga ML, Velarde R, Marco I, Lavin S, Alegre F, Cuenca R (2007) Fishhook lesions in loggerhead sea turtles. J Wildl Dis 43:737-741

Van Nierop MM, den Hartog JC (1984) A study of the gut contents of five juvenile loggerhead turtles, Caretta caretta (Linnaeus) (Reptilia, Cheloniidae) from the south-eastern part of the North Atlantic Ocean with emphasis on coelenterate identification. Zool Meded (Leiden) 59:35-54

Wallace BP, Heppell SS, Lewison RL, Kelez S, Crowder LB (2008) Impacts of fisheries bycatch on loggerhead turtles worldwide inferred from reproductive value analyses. J Appl Ecol 45:1076-1085

> Wallace BP, Lewison RL, McDonald SL, McDonald RK and others (2010) Global patterns of marine turtle bycatch. Conserv Lett 3:131-142

- Wang JH, Boles LH, Higgins B, Lohmann KH (2007) Behavioral responses of sea turtles to lightsticks used in longline fisheries. Anim Conserv 10:176-182

Watson JW, Epperly SP, Shah AK, Foster DG (2005) Fishing methods to reduce sea turtle mortality associated with pelagic longlines. Can J Fish Aquat Sci 62:965-981

Witzell WN (1999) Distribution and relative abundance of sea turtles caught incidentally by the U.S. pelagic longline fleet in the western north Atlantic ocean, 1992-1995. Fish Bull 97:200-211

Work TM, Balazs GH (2002) Necropsy findings in sea turtles taken as bycatch in the north Pacific longline fishery. Fish Bull 100:876-880

Submitted: September 25, 2009; Accepted: January 24, 2011 Proofs received from author(s): March 26, 2011 